\title{
A democracia corinthiana e ação sindical: a narrativa da integração entre o movimento alvinegro e o sindicato dos jogadores de futebol.
}

\author{
Heloisa Helena Baldy dos Reis* \\ Mariana Zuaneti Martins ${ }^{* *}$
}

\begin{abstract}
Resumo: O objetivo deste artigo é reconstituir a narrativa da integração de jogadores da Democracia Corinthiana com o Sindicato dos Atletas Profissionais, de modo a compreender como o movimento alvinegro influenciou a atuação sindical desta categoria. A partir de um levantamento histórico a partir de reportagens buscadas no jornal Folha de S. Paulo e na Revista Placar, e de uma entrevista semiestruturada concedida pelo jogador Wladimir, reconstituímos a narrativa dessa integração e discutimos a atuação sindical destes sujeitos. Deste modo, a participação dos jogadores corintianos no sindicato levava as demandas daquela experiência para o conjunto da categoria e possibilitava a criação de novas reivindicações, forjadas num ambiente relativamente mais autônomo.
\end{abstract}

Palavras-chave: Sindicatos. Condições de trabalho. Esportes.

\section{INTRODUÇão}

O objetivo deste artigo é reconstituir a narrativa da integração de jogadores da Democracia Corinthiana com o Sindicato dos Atletas do Estado de São Paulo (SAPESP), de modo a compreender como o movimento alvinegro influenciou a atuação sindical desta categoria.

\footnotetext{
*Programa de Pós-graduação em Educação Física Universidade Estadual de Campinas (Unicamp). Campinas, SP. Brasil. E-mail: helobaldy@yahoo.com

**Programa de Pós-graduação em Educação Física Universidade Estadual de Campinas (Unicamp). Campinas, SP. Brasil. E-mail: fale.com.marief@gmail.com
} 
A Democracia Corinthiana pode ser compreendida como as duas gestões do presidente Waldemar Pires à frente do Sport Club Corinthians Paulista, ocorridas entre março de 1981 e março de 1985. Nestas duas gestões, foram estabelecidas formas menos autoritárias de gestão do clube e da equipe de futebol, nas quais foi possível a participação dos jogadores em processos de tomadas de decisões ${ }^{1}$.

A pesquisa evidencia uma face do alcance da Democracia Corinthiana, que buscou expandir a atuação do grupo para o conjunto da categoria dos jogadores de futebol. Com isso, buscamos responder às seguintes questões: a discussão e as conquistas da experiência corintiana ficaram restritas a apenas um grupo seleto de jogadores profissionais "famosos" deste clube? Como esses sujeitos conseguiram expandir a amplitude de suas ações?

O debate a que se propôs este artigo busca a compreensão de como os jogadores de futebol da Democracia Corinthiana se integraram aos movimentos políticos, em especial ao sindical, no estado de São Paulo, discutindo suas condições de trabalho, de carreira e de vida. Compreendendo a Democracia Corinthiana como um produto e agente de seu tempo histórico, a situamos no contexto da primeira metade da década de 1980, quando emergiram os movimentos sociais que lutavam pela democratização da sociedade e o fim do regime militar. Dentre eles, ascendia o chamado novo sindicalismo, fazendo grandes greves e ganhando visibilidade, influenciando politicamente movimentos para além daqueles concentrados no ABC-SP (SADER, 2002). É neste contexto que se desdobram reflexões acerca de como os jogadores podem se colocar enquanto sujeitos políticos para intervir frente à estrutura do futebol brasileiro, a fim de modificá-la,

${ }^{1}$ Há distintas concepções sobre o que significou a Democracia Corinthiana. Entre seus diferentes sujeitos, existiam aqueles que defendiam que o movimento estava relacionado à participação nos processos de tomada de decisão, às votações que se desenvolviam no departamento de futebol e à tentativa de eleição de jogadores para o Conselho Deliberativo do clube. Havia ainda aqueles que a relacionavam aos direitos que foram empreendidos, como o de expressão e participação política ou à facultatividade da concentração. Havia ainda uma concepção por parte de um dos técnicos que negava a existência do diálogo e da democracia no clube. Por isso, compreendemos a Democracia Corinthiana como um movimento complexo, plural e que carregava uma diversidade de concepções sobre a sua própria existência (MARTINS; REIS, 2014).

Movimento, Porto Alegre, v. 20, n. 4, p. 1351-1371, out./dez. de 2014. 
algo que até então era privilégio apenas de uma elite de dirigentes ${ }^{2}$ de clubes e federações, ou até do governo militar, mas não dos principais protagonistas do espetáculo esportivo.

Esta análise sobre a participação dos jogadores corintianos no sindicato enseja uma reflexão acerca da existência e das possibilidades no movimento alvinegro de autonomia ${ }^{3}$, a qual declinou logo após a saída de Sócrates e teve seu fim após a derrota de Adilson Monteiro Alves ${ }^{4}$ para a presidência do Corinthians, em 1985. Havia uma grande dependência da diretoria para a sustentação do movimento, de modo que, a ameaça à continuidade deste estava sempre condicionada à demissão de Adilson ${ }^{5}$. Para nós, essa é a evidencia de uma fragilidade do movimento, que não guardava em si a autonomia dos jogadores de futebol, fato que poderia ter sido alcançado ou amadurecido com uma atuação mais sólida destes sujeitos no interior do sindicato. Conforme demonstraremos neste artigo, essa era uma reflexão então presente entre os próprios sujeitos do movimento e entre os jogadores naquele tempo histórico.

\section{Percurso metodológico}

Para compreendermos como se deu a atuação dos jogadores do Corinthians no sindicato utilizamos um levantamento histórico

\footnotetext{
${ }^{2} \mathrm{~A}$ profissionalização do futebol no Brasil gerou um conflito resolvido a partir da acomodação de uma elite ligada ao futebol no campo dirigente deste, enquanto cartolas, sendo o passe estabelecido para vincular o jogador ao clube. Deste modo, apesar de ter se aberto o espaço para que qualquer um pudesse se dedicar ao futebol, a profissionalização fez com que, ao mesmo tempo, os jogadores fossem colocados numa posição de não participarem do processo diretivo do futebol (DAMO, 2007).

${ }^{3} \mathrm{~A}$ partir de agora, quando nos referirmos a alvinegro (clube, movimento, jogadores) estamos falando do Corinthians, a partir da referência das cores de sua bandeira.

${ }^{4}$ Adilson Monteiro Alves assumiu a diretoria de futebol em novembro de 1981, quando o clube alvinegro passava por um momento de maus resultados. Ele tinha 35 anos, era sociólogo e não tinha nenhuma experiência com futebol. Sua indicação se deu porque seu pai era o então vice-presidente do clube. Por essa condição, segundo ele, assumiu o departamento procurando conversar com os jogadores e os técnicos sobre os seus rumos, e assim conduziu o departamento, mesmo com altos e baixos e contradições, até o momento em que perdeu a eleição em março de 1985.

${ }^{5}$ Sobretudo após a saída de Sócrates, que coincide com a incidência de maus resultados da equipe em campo, em diversas oportunidades o cargo de Adilson Monteiro Alves esteve ameaçado e, junto a este, a existência da democracia.
}

Movimento, Porto Alegre, v. 20, n. 4, p. 1351-1371, out./dez. de 2014. 
a partir de reportagens nas quais se noticiavam esses fatos durante o período da Democracia Corinthiana, de março de 1981 a março de 1985. Nossa pesquisa se desenvolveu neste recorte histórico no jornal Folha de S. Paulo e na Revista Placar ${ }^{6}$. A escolha desses meios se deu por retratarem aspectos políticos do futebol, quanto à organização da categoria. Utilizar os periódicos foi o modo de evidenciar opiniões diversas sobre o assunto e de ressaltar as falas do sujeito em seu tempo histórico sobre o entendimento do processo da Democracia Corinthiana. A escolha das duas fontes cumpriu em nossa pesquisa o papel de colocar em ordem ideias recorrentes e em evidência opiniões conflitantes sobre o assunto, a fim de retraçar a narrativa dessa integração a partir da forma como ela ganhou visibilidade pública. Por isso, apesar de os jornais não retratarem todos os eventos dessa integração, eles nos trazem aspectos dos debates e embates públicos empreendidos durante esse período. Tais acontecimentos também ganhavam grande notoriedade na imprensa em função do contexto histórico, marcado por ações sindicais em ascensão e bastante presente nos noticiários.

Além disso, realizamos uma entrevista semiestruturada ${ }^{7}$ (NEGRINE, 2004) com o jogador Wladimir, que foi membro da diretoria do Sindicato durante três gestões, de 1978 a 1980, 1980 a 1984, e eleito presidente da entidade em 1984. Essa entrevista foi importante para a compreensão da Democracia Corinthiana, bem como para o entendimento da relação de seus sujeitos com o movimento sindical. Por fim, contextualizamos a entrevista e as reportagens de modo a analisá-las à luz do debate sociológico sobre o futebol e a participação política e ação sindical.

${ }^{6} \mathrm{O}$ recorte da pesquisa engloba o período de março de 1981 a março de 1985. Há apenas duas exceções buscadas na Revista Placar de períodos anteriores. Uma delas, de 1979, sobre o sindicato paulista; e outra, uma edição especial da revista sobre um Censo do Futebol Brasileiro, de 1980. Buscamos essas edições por terem sido citadas em reportagens do período analisado. Foram utilizados os seguintes números da Revista Placar. 459; 675; 677; 694; 697; 703; 720. Do jornal Folha de S. Paulo, utilizamos reportagens da sessão esportiva dos seguintes dias: 03 abr. 1983; 21 jul. 1983; 13 jun. 1984; 14 jun. 1984; 2 set. 1984; 20 out. 1984; 1 nov. 1984; 2 nov. 1984.

${ }^{7}$ Os procedimentos empregados na pesquisa estão de acordo com os princípios éticos norteadores das Resoluções 196/96 e 251/97 do Conselho Nacional de Saúde.

Movimento, Porto Alegre, v. 20, n. 4, p. 1351-1371, out./dez. de 2014. 


\section{A CONFIGURAÇÃO DA PROFISSÃO DE JOGADOR DE FUTEBOL}

$\mathrm{Na}$ Democracia Corinthiana os jogadores alvinegros conseguiram algumas conquistas, como o direito à facultatividade da concentração, o direito de gerir seu tempo de não trabalho, a possibilidade de intervirem em seu próprio processo de trabalho, bem como o respeito ao direito de organização sindical e participação política, seja internamente ao clube ou no que tange à própria sociedade. Essas conquistas foram obtidas, em especial, após a entrada de Adilson Monteiro Alves como diretor de futebol. Após a derrota da chapa de continuidade da Democracia Corinthiana, em 1985, e a entrada de uma nova diretoria e de técnicos mais autoritários, os jogadores foram perdendo esses direitos conquistados.

Os jogadores colocavam em pauta, durante a Democracia Corinthiana, questões que não diziam respeito simplesmente à "inclusão", mas "ao direito de participar efetivamente da própria definição do sistema", concebendo, assim, uma nova forma de cidadania, algo forjado no Brasil na década de 1980, em conjunto com os demais movimentos sociais que lutavam pela democratização da sociedade (DAGNINO, 2004, p. 109). Por isso, o movimento atingiu patamares de reconhecimento para além do plantel alvinegro, expandindo-se para diversos clubes, que pretendiam adotar modelos semelhantes. Este foi o caso, por exemplo, do Sport Club Internacional, no qual o seu presidente disse ter implementado o modelo corintiano, mas sem ter permitido a possibilidade de os jogadores se manifestarem politicamente (SOUZA, 1984). O Clube de Regatas Vasco da Gama também afirmava, por meio de seu diretor de futebol, Paulo Angioni (1983), a existência de uma democracia dentro do que era também chamado de "Projeto Vascaíno". Concretamente, o que se apontava como elemento dessa democracia era a liberdade de expressão de todas as correntes políticas dentro do clube (1983). Podemos ver nesses casos exemplos de momentos em que a Democracia Corinthiana influenciou outros clubes e outros jogadores. Entretanto, o que fica

Movimento, Porto Alegre, v. 20, n. 4, p. 1351-1371, out./dez. de 2014. 
evidente nestes exemplos, como em outros (OS TÉCNICOS, 1983), é que a Democracia Corinthiana influenciou outros clubes, mas de forma limitada, no que diz respeito à organização dos jogadores, uma vez que essa influência pouco se pautava pelas principais conquistas obtidas pelo plantel corintiano. Além disso, a expansão de algumas das ideias do movimento ficava circunscrita aos clubes das primeiras divisões dos grandes centros futebolísticos. Nesse sentido, a reflexão do jornalista e técnico de futebol João Saldanha à época se colocava como um aviso para os jogadores:

[...] quanto à Democracia Corinthiana, reconheço que os jogadores estão dando um grito de alerta. Isso pode ser o ponto de partida para que a democracia chegue a todos os jogadores brasileiros. No país, a profissão ainda é um meio, não um fim. Os jogadores são $90 \%$ dos casos, boias-frias que rodam o país atrás de trabalho temporário, sem garantias nem segurança. A lei de passe ainda não está regulada, os sindicatos ainda não estão organizados. É por isso que os jogadores devem lutar. (OS TÉCNICOS, 1983, p. 58)

Nessa análise Saldanha corrobora as considerações de Florestan Fernandes sobre a transição democrática. Segundo o autor, para os trabalhadores, a questão central seria a conquista de sua autonomia por meio de instituições que se desvinculavam do controle da ditadura. Isso significava lutar não pela democracia representativa burguesa, mas fortalecer as "condições de auto-organização, de autoconsciência e de autoafirmação do proletariado - o que configura a realidade da democracia proletária dentro da ordem burguesa tão fechada e autocrática" (FERNANDES, 1980, p. 29). Para o autor, nas empresas isso se traduz na construção de comissões de fábrica; no movimento sindical, pelas organizações operárias livres e independentes, nas várias escalas necessárias, constituindo uma estratégia segundo a qual "os trabalhadores devem avançar no sentido de tornarem-se

Movimento, Porto Alegre, v. 20, n. 4, p. 1351-1371, out./dez. de 2014. 
socialmente válidos, pondo um paradeiro na tradição paternalistamandonista de 'morte civil' tácita e substituindo-a por uma nova tradição, de solidariedade de classe ativa, intransigente e militante" (FERNANDES, 1980, p. 30).

Para Saldanha (OS TÉCNICOS, 1983), a dinâmica da profissão de jogadores de futebol correspondia à categoria que não se apresentava como um bloco homogêneo de trabalhadores. Além daqueles jogadores famosos que estampavam as capas de jornais, a categoria era composta por uma massa de trabalhadores, espalhados pelo país, que conviviam sob as mais diversas condições de trabalho e de precariedade. Apesar de desde 1933 jogar futebol ser considerado uma profissão (DAMO, 2007), a regulamentação da mesma ainda era precária. Esta era dada pela Lei $\mathrm{n}^{0}$ 6.354, conhecida como Lei do Passe, de 1976. Como o próprio nome dela se refere, era baseada no princípio do "passe", que estabelecia que o atleta só poderia se transferir para outro clube mediante ao consentimento daquele que detivesse seu vínculo, instituindo um valor de troca para tanto, que se constituía como uma fonte de receitas ao clube, transformando os jogadores em parte de seu patrimônio líquido. Além disso, tal legislação pouco garantia direitos aos jogadores (BOUDENS, 2002). Pelo contrário, vinculava a vida do jogador à vontade de seu clube, de modo que desafiá-lo poderia ter um impacto negativo sobre toda a sua carreira, o que servia como um sustentáculo ao ideário paternalista do futebol.

A Revista Placar indicou em 1983 que, em meados da década de 1970, o futebol era responsável por uma fatia de 1,4\% do PIB nacional, o que demonstra um grande mercado relacionado a essa modalidade esportiva (VAMOS, 1983). Esse filão da indústria cultural concentrava, no ano de 1980, 7892 jogadores profissionais, distribuídos em 425 clubes $^{8}$. Já se verificava no futebol brasileiro uma concentração territorial do emprego desses trabalhadores, já

${ }^{8}$ Revista Placar, $1^{\circ}$ censo do futebol brasileiro, 17/10/1980. Caderno Especial. A reportagem não demonstrou o método de pesquisa que foi utilizado. Entretanto, foi o único trabalho do tipo encontrado à época. Ao que a reportagem sugere foram recolhidos dados sobre os clubes de três divisões de todos os estados do país.

Movimento, Porto Alegre, v. 20, n. 4, p. 1351-1371, out./dez. de 2014. 
que 2641 jogadores, cerca de um terço deles, eram do estado de São Paulo.

No que tange ao salário dos jogadores, os dados da Revista Placar, em 1980, demonstravam uma desigualdade em função das divisões dos clubes em que os jogadores atuavam. Aqueles dos times grandes (primeira divisão), cerca de 17,4\% do universo dos jogadores, tinham a média salarial de $\mathrm{Cr} \$ 31.840,00^{9}$; aqueles de times médios, cerca de 19,4\%, tinham a média salarial de $\mathrm{Cr} \$ 15.290,00^{10}$; e aqueles de times pequenos, cerca de $62,8 \%$ dos jogadores, tinham a média de $\mathrm{Cr} \$ 7.750,00^{11}$.

Deste modo, a configuração da profissão de jogador de futebol vai além daqueles que jogavam a primeira divisão dos grandes campeonatos. Contudo:

A densidade de representações de masculinidades associadas à prática do futebol [...] encobre as mazelas da profissão: a maioria dos jogadores é assalariada, suas carreiras são curtas, o auge é precoce, a reconversão improvável (DAMO, 2007, p. 24).

O poder de sedução da carreia do futebol encobre para os jovens o fato de que os que conseguem atingir esse patamar representam um percentual mínimo dos que ingressam na carreira. Conforme apontou Arlei Damo (2007), trata-se de uma carreira bastante precarizada, com o agravante de ter uma duração curta e a possibilidade mínima de reconversão em outra carreira após deixar de ser atleta. Diante desse cenário de imensas desigualdades que se ergue a consideração de João Saldanha: foi necessário expandir as conquistas para a categoria e isso implicou considerar a atuação no sindicato dos atletas.

\footnotetext{
${ }^{9}$ Valores corrigidos nesse trabalho segundo índice IPC-FIPE corresponderiam a $\mathrm{R} \$ 1622,66$. Este valor corresponderia a cerca de seis salários mínimos nos valores de outubro de 1981.

${ }^{10}$ Valor corrigido: $\mathrm{R} \$ 779,23$. Aproximadamente três salários mínimos, segundo os valores da época.

${ }^{11}$ Valor corrigido: $\mathrm{R} \$ 394,96$. Este valor corresponderia a pouco mais de um salário mínimo, com valores da época.
}

Movimento, Porto Alegre, v. 20, n. 4, p. 1351-1371, out./dez. de 2014. 


\section{A PARTICIPAÇÃO DOS JOGADORES DA DEMOCRACIA CORINTHIANA NO SINDICATO}

A narrativa da participação dos jogadores da Democracia Corinthiana no Sindicato dos Atletas do Estado de São Paulo (SAPESP) deve ser tecida a partir da participação de Wladimir, que fez parte do Sindicato dos atletas, a partir de 1978, durante a gestão do jogador Palhinha ${ }^{12}$. Na gestão seguinte, em 1980, com a entrada de Valdir Peres como presidente, Wladimir foi tesoureiro e, por fim, em 1984, elegeu-se presidente. Além de Wladimir, figura do movimento alvinegro que mais ativamente atuou no sindicato, outros jogadores participaram publicamente dos debates acerca do sindicalismo no futebol, como Sócrates, Daniel Gonzalez, Leão, Casagrande e Juninho. Destes, durante o período da Democracia Corinthiana, Juninho e Casagrande foram diretores sindicais ambos, além do próprio Wladimir, eram filiados ao Partido dos Trabalhadores, demarcando uma atuação política para além do clube alvinegro. Casagrande, por ser dirigente sindical, foi alvo de uma polêmica dentro do clube, quando a diretoria corintiana queria dispensá-lo, mas, em função do mandato que ele cumpria, não pôde porque era ilegal ${ }^{13}$.

Durante a Democracia Corinthiana, o sindicato dos atletas ganhou bastante publicidade nos meios de comunicação, o que torna interessante a reconstrução de sua atuação, por permitir observar os

\footnotetext{
${ }^{12}$ Palhinha era jogador do Corinthians também naquele momento e, segundo depoimento de Wladimir, foi ele quem o convidou para fazer parte do sindicato. Palhinha foi eleito vicepresidente do sindicato na chapa presidida por Leão, em 1978. Entretanto, como este foi transferido do futebol paulista para o mineiro, Palhinha assumiu a presidência (CARDOSO, Maurício. Um líder paulista, uai. Revista Placar, nº 459, 9/2/1979, p. 6-8).

${ }^{13} \mathrm{Em}$ função de um afastamento temporário do técnico Jorge Vieira, por adoecimento, Casagrande deu uma declaração de que ele já não era mais o treinador da equipe, afirmando que o preparador físico Helio Maffia estaria exercendo o cargo. Jorge Vieira, então, tentou excluir Casagrande de uma delegação, mas não obteve o respaldo de Adilson Monteiro Alves. A consequência foi que o técnico pediu demissão. Neste episódio, a diretoria decidiu punir Casagrande, colocando-o à venda, contrariando a vontade do jogador, que queria permanecer no clube. Em função de ele ser dirigente sindical, o Corinthians não pôde vendê-lo, uma vez que tal mandato lhe garantiria estabilidade no emprego (NINGUÉM pode mandar Casagrande embora. Folha de São Paulo, P. 26,13/06/1984; BORGE, Ari. Lula com Sócrates defende o sindicalista Casagrande, Folha de São Paulo, p.28, 14/06/1984 ).
}

Movimento, Porto Alegre, v. 20, n. 4, p. 1351-1371, out./dez. de 2014. 
entrelaçares da integração da experiência na entidade sindical. Até então, a atuação do SAPESP tinha sido bastante tímida, com uma baixa taxa de adesão - entre 800 e 1.200 sócios, num universo de cerca de 3 mil jogadores profissionais em São Paulo (JOGADORES, 1983). Esta representatividade pequena era justificada como um problema da gestão do sindicato, que não se interessava em buscar uma quantidade maior de associados e fortalecer a entidade. Em 1983, Zé Mário, ex-jogador e técnico do Botafogo, dizia que os problemas do sindicato paulista eram fruto do desinteresse da presidência da entidade, falta de visão administrativa e incompetência. Segundo ele, havia uma diferença muito grande entre o sindicato de São Paulo e do Rio de Janeiro, pois neste praticamente todos os jogadores eram sócios da entidade (JOGADORES, 1983)

Naquele mesmo ano, durante a gestão presidida pelo goleiro Valdir Peres, os membros da Democracia Corinthiana deram publicidade às discussões sobre os rumos do sindicato. $\mathrm{O}$ jogador Sócrates, uma das principais lideranças do movimento alvinegro, criticou o presidente da entidade, em função de o sindicato não ter demonstrado interesse, naquele momento, em dialogar com sua base. Na ocasião, Sócrates falou sobre a importância do sindicato, como um instrumento que possibilitava criar um plano de ação, construído com ampla participação dos jogadores, e que representasse as demandas de toda a categoria. A principal pauta de reivindicação apontada pelo jogador e, segundo ele, negligenciada pelo sindicato, era uma proposta de abolição da Lei do Passe, mas que buscasse nessa proposição resolver as contradições que estavam presentes nos patamares mais precarizados da categoria, de modo a não defender uma mudança que fosse prejudicial à maioria dos jogadores. (SOCRÁTES, 1983, p. 26).

Sócrates se interessou pela atividade sindical em função do sucesso da Democracia Corinthiana, que tinha feito com que ele vislumbrasse a possibilidade de ampliar este projeto, a partir do sindicato:

[...] eu sempre tentei mudar alguma coisa na estrutura do futebol, através do micromundo

Movimento, Porto Alegre, v. 20, n. 4, p. 1351-1371, out./dez. de 2014. 
do meu clube, mas nunca consegui qualquer retorno. Acabava frustrado e sem ânimo para estender essa luta para um universo maior. Mas em 1982 tivemos sucesso, o grupo avançou no trabalho de arejar um pouco o ambiente e romper esse conformismo, o reacionarismo que impera na estrutura em que vivemos diariamente. Tendo êxito, ainda que parcial, no Corinthians, eu me animei a partir para um voo mais alto, para um projeto que vá buscar os problemas e as soluções na base da categoria. ${ }^{1}$ (SOCRÁTES, 1983, p. 26).

O problema da representatividade do sindicato fazia parte do tom da crítica de Sócrates à diretoria da entidade, a qual se dirigia principalmente, ao fato de, apesar do discurso de portas abertas, a mesma não se aproximar do jogador para entender as demandas da categoria. Conforme a fala do jogador, nos clubes pequenos, os profissionais tinham menos garantias. Para pensar mudanças na Lei do Passe, Sócrates insistia que seria necessário percorrer o interior, a fim de enxergar os problemas dos clubes pequenos, pois era neles que residiam as contradições que o sindicato precisava resolver (SOCRÁTES, 1983, p. 26).

Além da questão da representatividade, outro aspecto da crítica de Sócrates à diretoria de Valdir Peres se referia à omissão do sindicato com relação aos movimentos sindicais que ocorreram no ano de 1983. Em julho daquele ano, diante da convocação de um dia de greve geral, alguns jogadores se manifestavam contra a partida, preferindo um adiamento das partidas que ocorressem naquela data. O jogador Sócrates, assim como Casagrande, era favorável à participação dos atletas na greve geral. "Nem jogo, nem treino. Isso deveria partir do nosso sindicato", o que não aconteceu (CORINTHIANS, 1983, p. 24). Em entrevista à Revista Placar, Sócrates criticou duramente o sindicato por se omitir nessa ocasião, afirmando ser tarefa da entidade se unir à classe (SOU, 1983, p.19). Isso representa uma crítica do movimento à forma como o sindicato não se envolvia nas lutas dos trabalhadores do

Movimento, Porto Alegre, v. 20, n. 4, p. 1351-1371, out./dez. de 2014. 
Brasil. É importante relembrar, nesse caso, que uma das marcas da Democracia Corinthiana dizia respeito ao engajamento de seus atletas no movimento das "Diretas Já".

O ponto de maior integração da Democracia Corinthiana ao sindicato ocorreu quando Wladimir assumiu a presidência, gestão da qual participaram também Juninho e Casagrande. Alinhado com os debates advindos do novo sindicalismo (SADER, 2002), Wladimir queria "transformar o futebol numa estrutura sindical eficiente, capaz de acabar com o paternalismo e a ingerência política dos cartolas na profissão". Dizia que havia dificuldades, em especial que "infelizmente a essência do futebol profissional é o confronto; a derrota de um é a vitória de outro" (WLADIMIR, 1984, p. 27). Segundo ele, "a gente existe para jogar contra. E isso gerava uma certa animosidade, uma certa distância, na verdade. Então, a nossa profissão tem essa peculiaridade, essa distinção com relação a outras" ${ }^{\prime 14} \mathrm{e}$ este aspecto tornava difícil a unidade da categoria.

Para Wladimir, apesar de ter havido alguma evolução no trato entre o jogador e dirigentes, o paternalismo continuava existindo em larga escala no futebol profissional: "mas lamentavelmente isso também ocorre em outras áreas, como na política, onde o governo resolve tudo. A gente tem é de partir para a luta. No sindicato isso acontece com frequência" (WLADIMIR, 1984, p. 27). A fala do jogador corrobora os estudos sobre a cultura política no país, cuja história da cidadania a faz concedida, pois está calcada na ideia dos direitos vividos enquanto dádivas, frutos de trocas em uma relação de subserviência (SALES, 1994), do modo que o chamado 'paternalismo' no trato do jogador de futebol não é exclusivo dessa esfera, uma vez que está presente na própria forma da conformação inicial da cidadania no Brasil. Santos (1979) afirma que a cidadania no Brasil surgiu, na década de 1930, de forma regulada, destacando o forte papel do Estado em definir quem era cidadão, segundo o qual apenas tinha direitos aquele que trabalhava e cuja profissão

\footnotetext{
${ }^{14}$ Wladimir em entrevista.
}

Movimento, Porto Alegre, v. 20, n. 4, p. 1351-1371, out./dez. de 2014. 
era reconhecida pelo Estado. Sendo assim, está presente na cultura política brasileira o "paternalismo", entendido tanto como relação de concessão, como a forte regulação de um agente "superior" nas relações. Ao adentrar no sindicato, a ideia de Wladimir se pautava em romper com essa cultura política, embate que em alguma medida a Democracia Corinthiana travava ao dar voz ao jogador de futebol e ao participar dos movimentos de democratização brasileira.

Para fortalecer o sindicato, uma das medidas tomadas na gestão de Wladimir foi fazer uma campanha para aumentar o número de associados. De 600 passaram para 3 mil sócios, algo que era só o primeiro passo para esse fortalecimento, visto que, para ele, além disso, era necessária uma conscientização do jogador. Para avançar nos debates sobre as condições de trabalho e expandir a ação do sindicato, a gestão dele criou um jornal da categoria e pretendia expandir sua ação para fortalecer o jurídico e implantar assistência médica, principalmente para os desempregados. Segundo Wladimir,

[...] o futebol brasileiro necessita [em 1984] de uma reestruturação, tem que ser visto como atividade empresarial, não viva apenas das rendas dos jogos. Estamos trabalhando também junto aos garotos para que eles não se iludam quando se tornarem profissionais, não pensem que vão ser necessariamente um Zico ou um Sócrates (WLADIMIR, 1984, p. 27).

Uma das questões mais importantes, segundo Wladimir (O DESAFIO, 1984), era a Lei do Passe, ressaltando que:

[...] passe livre, na estrutura atual do futebol brasileiro, é sinônimo de instabilidade no emprego. Achamos que a Lei do Passe tem que ser revogada, mas como uma nova forma de relacionamento entre patrão e empregado. Temos que começar com as divisões inferiores. Quando o jogador começasse em um clube teria a liberdade de aceitar ou não a sua vinculação (O DESAFIO, 1984, p. 23).

Movimento, Porto Alegre, v. 20, n. 4, p. 1351-1371, out./dez. de 2014. 
Esta luta representa um ponto de intersecção entre as lutas travadas pela Democracia Corinthiana e a plataforma do sindicato. Isso porque, por mais que a primeira não tenha tocado embates relacionados ao "passe", ao atuar no sindicato, essa perspectiva entrou no horizonte, defesa evidenciada na fala de Wladimir e em depoimentos de Sócrates. O interessante ainda é que o debate sobre a Lei do Passe ocorreu, na perspectiva de ambos, ponderado pela necessidade de conciliá-lo à luta por melhores condições de trabalho, passos dados dentro do plantel corintiano ${ }^{15}$.

Além disso, na fala de Wladimir fica evidente uma preocupação com a precariedade da carreira de jogador de futebol, atribuindo ao passe uma segurança que o contrato livre não necessariamente atribuiria. Todavia, para o jogador, a falsa segurança proporcionada pela vinculação por meio do passe não era motivo para sua defesa. Por isso, garantir estabilidade na carreira e segurança de emprego no mundo do livre contrato dependeria da própria ação do sindicato em lutar por direitos e condições mínimas básicas na profissão que proporcionassem a plena realização do direito ao trabalho como jogador de futebol. Portanto, fundamental para a extinção da Lei do Passe sem piora nas condições de trabalho seria o fortalecimento da categoria e da entidade dos atletas.

Como parte dessa plataforma sindical de defesa de melhores condições de trabalho, outra demanda representada na gestão de Wladimir à frente do sindicato, em entrevista concedida a uma das autoras em 2012, era a fixação de um piso salarial, que não foi adiante, segundo o jogador,

\footnotetext{
${ }^{15}$ Nesse sentido, a Democracia Corinthiana, apesar de se entender como um movimento que buscava o fim do paternalismo no futebol brasileiro (frente ao conservadorismo tão presente nesse ambiente), não conseguiu perceber e imputar como nó da questão a Lei do Passe, uma vez que essa pauta não ganhou relevância. A questão de se o jogador deveria se concentrar teve mais peso que essa reivindicação. Eles chegaram mesmo a discutir sobre seu próprio processo de trabalho, alcançando a possibilidade de escolher um deles para geri-lo, como técnico. Entretanto, os jogadores desse movimento não se colocaram contra um processo tão naturalizado que era a propriedade do passe do jogador de futebol, ponto que nenhum dirigente tocava, para a construção de relações mais modernas no futebol. Dessa forma, apesar de no sindicato os jogadores pautarem essa questão, em especial nas entidades Paulista e Carioca, a Democracia Corinthiana não logrou atingir um patamar de organização autônoma que permitisse potencializar essa luta, contra algo tão arraigado e tão naturalizado, tanto quanto arcaico, que era a Lei do Passe.
}

Movimento, Porto Alegre, v. 20, n. 4, p. 1351-1371, out./dez. de 2014. 
a gente queria o piso salarial para todas as categorias, desde a de base até a profissional. Nós queríamos acabar com a Lei do Passe. Essas eram as nossas maiores brigas, nossos maiores desejos. O piso, ele acabou não tendo consenso, por causa da individualidade de cada um - do valor individual de cada um (em entrevista concedida a uma das autoras em 2012).

Durante sua gestão à frente do sindicato, houve enfrentamento à Federação Paulista de Futebol, em 1984, quando o jogador Mario Sérgio, do Palmeiras, foi pego no exame antidoping. A diretoria do clube palmeirense tentava adiar seu julgamento de modo que ele pudesse continuar disputando partidas sem que fosse punido, até o final do campeonato paulista. A postura do presidente do Sindicato, além de oferecer a estrutura jurídica da entidade para ajudar na defesa do jogador, era também de que se paralisasse o campeonato até que o julgamento ocorresse, uma vez que proceder sem essa interrupção do campeonato, significava não atribuir validade ao exame antidoping e descredibilizar toda a categoria que não fazia uso de substâncias ilícitas. Segundo o jogador, ele chegou a ameaçar organizar uma greve dos jogadores, caso o presidente da Federação Paulista não tomasse uma atitude:

Ele subestimou a nossa capacidade aí, e a gente ia parar mesmo. Não paramos porque eles julgaram o Mario Sérgio. O cara estava sob suspeita; a categoria estava sob suspeita. Julgou o cara e ele foi condenado. Foi da minha cabeça, eu tava reunindo com o presidente da federação, na verdade eles atendem interesses do clube, para os atletas eles não estão nem aí. Então, falei 'o seguinte, senhor Marin, a gente para o campeonato'. E ele disse, 'não'. E daí eles julgaram (Wladimir, em entrevista concedida a uma das autoras, em 2012).

Esse episódio teve o apoio da diretoria do Corinthians, o que fez com que a atuação do sindicato fosse criticada, como defensora dos interesses da equipe (CORINTHIANS, 1984; O SÃO PAULO,

Movimento, Porto Alegre, v. 20, n. 4, p. 1351-1371, out./dez. de 2014. 
1984). Esse evento demonstra um dos pontos controversos da integração entre a Democracia Corinthiana e o sindicato. Por isso, por mais que a experiência corintiana fosse um exemplo a ser seguido por outros clubes, o que garantiria sua radicalidade e seu potencial transformador, do ponto de vista dos direitos dos jogadores, seria sua organização autônoma à diretoria, questão que era contraditória nela, dada a grande dependência que havia de Adilson Monteiro Alves.

A organização autônoma dos jogadores poderia fazer com que escapassem da lógica da participação regulada ou concedida. Ter isso em vista era fundamental, porque se a diretoria, em geral, apoiava e até incentivava ${ }^{16}$ a participação nos sindicatos, para evidenciar o conflito de interesses entre os jogadores e os clubes seria necessário ter força e independência. Apenas desse modo os jogadores não ficariam reféns da concordância ou dos limites impostos pelos dirigentes dos clubes, podendo questioná-los e avançar para além do projeto de gestão que propunham. A questão da Lei do Passe, por exemplo, era uma demanda que não contava com o apoio dos dirigentes e dependia da força da categoria para se impor enquanto demanda a ser atendida.

Em reportagem na Revista Placar, verifica-se um debate entre diversos jogadores de futebol acerca do significado da Democracia Corinthiana. Dentre as opiniões favoráveis à experiência está a de Palhinha, que atribuiu o sucesso da experiência "à mentalidade aberta do dirigente Adilson Monteiro Alves" (DEMOCRACIA, 1983, p.18). O jogador reconheceu a dependência do protagonismo do dirigente para a existência da Democracia Corinthiana. Isso explicita um sentido de concessão da participação, ofuscando o de conquista dos jogadores e o do reconhecimento dos direitos. Entretanto, cabe ressaltar que, uma vez criado esse espaço, ele não serviu para demonstração de subserviência aos dirigentes, mas foi disputado pelos jogadores, ainda que, até pela sua origem, mantivesse uma lógica limitada a elementos que não interferissem

\footnotetext{
${ }^{16}$ Adilson Monteiro Alves incentivava a participação política dos jogadores, seja nos movimentos das "Diretas Já" ou no sindicato (SANTOS, 1990).
}

Movimento, Porto Alegre, v. 20, n. 4, p. 1351-1371, out./dez. de 2014. 
diretamente nos planos de gestão dos dirigentes. Por isso que o jogador Reinaldo, do Atlético Mineiro, reafirmava que para a experiência ter sucesso era necessário que "os clubes deixassem de ser dirigidos emocionalmente e nossos sindicatos ganhassem força e representatividade [...]. O grande problema da democracia no futebol, atualmente, está no fato de o jogador não saber lutar organizadamente" (DEMOCRACIA, 1983, p.18).

Esta narrativa traz à tona as dificuldades da organização do sindicato dos atletas profissionais. Em primeiro lugar, demonstra como os jogadores renomados normalmente se distanciam do conjunto da sua própria categoria profissional. Eles têm espaço para ter suas habilidades reconhecidas, enquanto a maioria dos jogadores tem essa possibilidade muito reduzida, dada a precariedade de seus empregos e das ligas onde jogam, as quais se distanciam muito daquelas que ocupam o topo do show business, das principais competições esportivas do país. Aquele que conseguiu se estabelecer na profissão julga-se que foi em função de seu mérito. Dessa forma, neste estrato da elite dos jogadores profissionais, conseguimos relacionar a categoria com as profissões de classe média, nas quais a especificidade do trabalho é mais o sentido de ser tarefa "não manual", não no sentido fisiológico do termo, mas por requerer um “dom" e um conhecimento construído e adquirido. Neste estrato, é característica a pequena participação nos sindicatos, em função de estes sujeitos creditarem seus ganhos salariais e profissionais predominantemente ao mérito individual (BOITO JUNIOR, 2004, p. 223-225). Para os trabalhadores apegados a essa ideologia meritocrática, as lutas sindicais seriam necessárias só para aqueles "que têm que compensar, recorrendo ao uso da força coletiva, à falta de dons e de méritos pessoais e o trabalho simples e degradado que executam" (BOITO JUNIOR, 2004, p.225). Entretanto, apesar de produzir esse efeito de isolamento particular, o "meritocratismo" pode articular-se ao sindicalismo, na medida em que "desloca a ênfase do mérito individual para a profissão", calcado na defesa de uma determinada profissão na hierarquia social (BOITO JUNIOR, 2004, p. 228). Mas apenas essa forma de demanda não contempla a maioria dos jogadores, que pouco reconhecimento tem na

Movimento, Porto Alegre, v. 20, n. 4, p. 1351-1371, out./dez. de 2014. 
profissão. Por isso, apesar de ser importante que os jogadores mais famosos participem, é fundamental ter em vista que a categoria dos futebolistas é mais ampla, de modo que aqueles que conseguem se estabelecer são poucos. Isso imputa a necessidade de pensar uma atuação que foque na categoria como um todo e que, portanto, se distancie do sindicalismo meritocrático, porque este não consegue ter a abrangência suficiente para colocar em primeiro plano as questões latentes para o conjunto da categoria.

\section{Considerações finaIS}

A Democracia Corinthiana, a um só tempo, incentivava a participação dos jogadores e a limitava, dada a dependência existente entre estes e a diretoria e o projeto de gestão empreendido pelo clube alvinegro. A integração da Democracia Corinthiana ao Sindicato dos Atletas Profissionais apresentava duas possibilidades: estender a todos os jogadores brasileiros as conquistas e os debates políticos empreendidos no Corinthians; e um processo concreto que avançasse para além do que permitiam os limites da gestão corintiana. Para que se concretizassem, era necessário que se fortalecesse o sindicato, colocando-o como interlocutor dos anseios por melhores condições de trabalho, que muitos jogadores viam representadas no movimento corintiano.

Por mais que a Democracia Corinthiana tenha criado condições de manifestação dos jogadores dentro do clube corintiano e, com isso, tenha atribuído condições melhores de trabalho, o movimento não conquistara a autonomia de classe da categoria para conseguir avançar para rumos que permitissem tocar em questões que a dependência da diretoria atrapalhava e que lograssem alçar voos mais altos para toda a categoria dos jogadores de futebol. A experiência alvinegra sustentava uma permanente tensão entre a integração aos contornos do novo sindicalismo - as reivindicações por uma nova cidadania, contrária aos ideais arcaicos do paternalismo - e a manutenção de uma forma de participação regulada - tal qual a que forjava a cidadania brasileira nos primórdios de sua gestação.

Movimento, Porto Alegre, v. 20, n. 4, p. 1351-1371, out./dez. de 2014. 
Nesse sentido, ir ao sindicato significava expandir a experiência da Democracia Corinthiana enquanto modernização das relações de trabalho, direito de negociar e de ser trabalhador de "livre" contrato. O sindicato deveria ser o lugar para a criação dessa autonomia.

Democracia corinthiana y sindicalismo: la narrativa de la
integración entre el movimiento corinthiano y el sindicato de
los jugadores de futbol.
Resumen: El objetivo de este trabajo es reconstruir la narrativa de
la integración de los jugadores de la Democracia Corinthiana con
el Sindicato de Atletas Profesionales, con el fin de entender cómo
el movimiento influyó sobre la actividad sindical de esta categoría.
A partir de un estudio histórico, buscado en reportajes del periódico
Folha de São Paulo y de la revista Placar, y una entrevista
semiestructurada con el jugador Wladimir, reconstituimos la
narrativa de esta integración y discutimos la actividad sindical
de estos agentes. Por lo tanto, la participación de los jugadores
"corinthianos" en el sindicato posibilitó expandir las exigencias de
esa experiencia a toda la clase y permitió la creación de nuevas
solicitudes, que se construyeron en un contexto relativamente más
autónomo.
Palabras clave: sindicatos, condiciones de trabajo, deportes.

Corinthians democracy and unionism: the narrative of the integration between the "corinthians' movement" and the football players union.

Abstract: The aim of this paper is to reconstruct the narrative of the integration between the football players from Corinthians Democracy and the Professional Athletes Union, in order to explain how that movement influenced union activity in the category. From a historical survey on articles published by newspaper Folha de São Paulo and in Placar magazine, and a semi-structured interview with player Wladimir, we reconstituted the narrative of that integration and discussed the labor union activity of these subjects. Thus, participation by Corinthians's players in the union expanded the demands of that experience to the whole class and enabled the creation of new demands created in a relatively more autonomous context.

Keywords: labor unions; working conditions; sports. 


\section{REFERÊNCIAS}

ANGIONI, Paulo. Existe uma democracia dentro de São Januário. Revista Placar, n. 693, p. 33,2 set. 1983 .

BOITO JUNIOR, A. Classe média e sindicalismo. Politeia: história e sociedade, Vitória da Conquista, v. 4, n.1, p. 211-234, 2004.

BORGE, A. Lula com Sócrates defende o sindicalista Casagrande. Folha de S. Paulo, São Paulo, 14 jun., 1984.

BOUDENS, E. Relações de trabalho no futebol brasileiro: Lei do Passe, a tentativa de sua extinção (PL $\left.n^{\circ} 1.159 / 95\right)$ e a proposta de regulamentação do INDESP. Brasília: Câmara dos Deputados, 2002.

BRASIL. Lei $n^{\circ} 6.354$, de 2 de setembro de 1976. Dispõe sobre as relações de trabalho do atleta profissional de futebol, e dá outras providências. Diário Oficial [da República Federativa do Brasil], Brasília, v. 114, n. 170, p. 11687-8, 3 set. 1976. Seção 1, pt. 1.

CARDOSO, Maurício. Um líder paulista, uai. Revista Placar, São Paulo, n. 459, , p. 6-8, 9 fev.1979

CORINTHIANS em Campinas, sob protestos. Folha de S. Paulo, São Paulo, 21 jul.1983, p. 24.

CORINTHIANS exige providências. Folha de S. Paulo, São Paulo, 02 nov. 1983, p. 26.

DAGNINO, E. Sociedade civil, participação e cidadania: de que estamos falando?. In: MATO, Daniel. (ed.). Políticas de Ciudadanía y Sociedad Civil en tiempos de globalización. Caracas: FaCES, Universidad Central de Venezuela, 2004.

DAMO, Arlei Sander. Do dom à Profissão: a formação de futebolistas no Brasil e na França. São Paulo: Aderaldo \& Rithschild, 2007.

DEMOCRACIA em debate. Revista Placar, São Paulo, n.675, 29 abr. 1983, p. 16-18.

FERNANDES, F. Brasil: em compasso de espera: pequenos escritos políticos. São Paulo: HUCITEC, 1980.

JOGADORES discutem sindicalismo mais forte. Folha de S. Paulo, São Paulo, 3 abr., , p. 26, 1983.

MARTINS, M. Z. REIS, H. H. B. Significados de democracia para os sujeitos da Democracia Corinthiana. Movimento, Porto Alegre, v. 20, n. 1, p. 81-101, jan. 2014.

NEGRINE, A. Instrumentos de Coleta de Informações na pesquisa qualitativa. In: TRIVINOS, A. N. S.; MOLINA NETO, V. (orgs). A pesquisa qualitativa na educação fisica : alternativas metodológicas. Porto Alegre : Ed. Universidade UFRGS : Sulina, 2004.

NINGUÉM pode mandar Casagrande embora. Folha de S. Paulo, São Paulo, 13

Movimento, Porto Alegre, v. 20, n. 4, p. 1351-1371, out./dez. de 2014. 
A democracia corinthiana e ação sindical...

jun. 1984, p. 26 .

O DESAFIO de um novo jogo. Revista Placar, São Paulo, n. 719, 02 mar. 1984, p. $20-23$.

O SÃO PAULO também vai recorrer. Folha de S. Paulo, São Paulo, 01 nov. 1984, p. 27.

OS TÉCNICOS discutem a democracia. Revista Placar, São Paulo, n.677, p.56-58, 13 maio 1983.

SADER, E. Quando os novos personagens entram em cena: experiências e lutas dos trabalhadores da grande São Paulo - 1970-1980. 5. ed. São Paulo: Paz e Terra, 2002.

SALES, T. Raízes da Desigualdade Social na Cultura Brasileira. Revista Brasileira de Ciências Sociais, São Paulo, n.25, p. 26-37, 1994.

SANTOS, L. T. Futebol empresa e a Democracia Corinthiana: uma administração que deu dribling na crise. 1990. 169f. Dissertação (mestrado) - Universidade Estadual de Campinas, Instituto de Filosofia e Ciencias Humanas, Campinas, SP.

SANTOS, W. G. Cidadania e Justiça. Rio de Janeiro, RJ: Campus, 1979.

SÓCRATES não quer só carteirinha. Folha de S. Paulo, São Paulo, p. 26, 3 abr.1983.

SOU radical até mudar de ideia. Revista Placar, São Paulo, 9/9/1983, p. 19.

SOUZA, Nilson.A abertura colorada. Revista Placar, São Paulo, São Paulo, n. 710 de 9 mar.1984, p. 40-41.

SOUZA, R. Agora é o Corinthians que quer melar o campeonato. Folha de S. Paulo, São Paulo, p. 22, 20 out. 1984.

VAMOS mudar o futebol. Revista Placar, São Paulo, n 703, 11 nov. 1983, p. 22-23.

WLADIMIR quer sindicato sem paternalismos. Folha de S. Paulo, São Paulo, 02 set. 1984 , p. 27.

\section{Financiamento: CAPES}

Endereço para correspondência:

Programa de Pós-graduação em Educação Física, Universidade Estadual de Campinas (Unicamp). Rua Érico Veríssimo, 701 - Cidade Universitária, Campinas, SP, CEP: 13083-851.

Recebido em: 05.11.2013

Aprovado em: 22.08.2014

Movimento, Porto Alegre, v. 20, n. 4, p. 1351-1371, out./dez. de 2014. 